\title{
WWW.MMM (no pun intended) : or the reconstruction of interactivity in marketing
}

Citation for published version (APA):

de Ruyter, J. C. (2000). WWW.MMM (no pun intended) : or the reconstruction of interactivity in marketing. Maastricht University. https://doi.org/10.26481/spe.20000324kr

Document status and date:

Published: 24/03/2000

DOI:

$10.26481 /$ spe. $20000324 \mathrm{kr}$

Document Version:

Publisher's PDF, also known as Version of record

\section{Please check the document version of this publication:}

- A submitted manuscript is the version of the article upon submission and before peer-review. There can be important differences between the submitted version and the official published version of record.

People interested in the research are advised to contact the author for the final version of the publication, or visit the DOI to the publisher's website.

- The final author version and the galley proof are versions of the publication after peer review.

- The final published version features the final layout of the paper including the volume, issue and page numbers.

Link to publication

\footnotetext{
General rights rights.

- You may freely distribute the URL identifying the publication in the public portal. please follow below link for the End User Agreement:

www.umlib.nl/taverne-license

Take down policy

If you believe that this document breaches copyright please contact us at:

repository@maastrichtuniversity.nl

providing details and we will investigate your claim.
}

Copyright and moral rights for the publications made accessible in the public portal are retained by the authors and/or other copyright owners and it is a condition of accessing publications that users recognise and abide by the legal requirements associated with these

- Users may download and print one copy of any publication from the public portal for the purpose of private study or research.

- You may not further distribute the material or use it for any profit-making activity or commercial gain

If the publication is distributed under the terms of Article $25 \mathrm{fa}$ of the Dutch Copyright Act, indicated by the "Taverne" license above, 


\section{WWW.MMM (no pun intended) or the reconstruction of interactivity in marketing}

Rede in verkorte en vrije vorm uitgesproken bij de aanvaarding van het ambt van bijzonder hoogleraar Interactieve Marketing aan de Faculteit der Economische Wetenschappen en Bedrijfskunde van de Universiteit Maastricht op vrijdag 24 maart 2000 door

Dr. Ko de Ruyter 
Co Ko Ruyter Maastricht 2000 
And the end of all our exploring Will be to arrive where we started And know the place for the first time

T.S. Eliot, Littlle Gidding

maar't is zoals het gaat

Blaf, De Zeeuwse Kust 


\section{PUNS, PARADIGMS AND MARKETING P'S}

\section{LADIES AND GENTLEMEN,}

One could safely say that to the vast majority of you, the acronym WWW means World Wide Web. Perhaps even to some of the marketing people in the aldience, its semantics may trigger associations of e-commerce and the future present of our field. There are those, however, for whom the acronym has come to mean What Went Wrong? Those are the companies that misinterpreted the acronym in its reversed form (MMM), underestimating the evolutionary dynamics of the relationship between Medium, Message and Meaning, or was it simply Myopic Marketing Management? Let me explain why inverting acronyms is not merely an academic 'Spiel', or why there is no pun intended.

\section{Britannica no longer rules the waves}

One of the most authoritative sources of information in the western world has been the Encyclopaedia Britannica. Founded as early as the eighteenth century, the Britannica evolved into a prestigious, multivolume institution, as well as a marketing success story with brand extensions, such as atlases and yearbooks to match. However, in a real time market place, history seems worth less than the future. Britannica sales suddenly dropped by over $80 \%$ in the last decade of the $20^{\text {th }}$ century (Melcher 1997). Interactive, CD-ROM-based alternatives (i.e., literally killer applications) were introduced by software companies that simply licensed its content from Britannica's competitors. After finally succumbing to the new medium, Britannica discovered that it was impossible to create an interactive version because its once superior intellectual content exceeded storage limitations. The company was put up for salle at a bargain price in 1996. In their analysis of what went wrong, Evans and Wurster (2000) state that the link between the message and the medium has literally been blown to bits. In markets governed by the rules of infonomics, success will depend on understanding and leveraging a firm's interactive albility, whether it is in the encyclopedia, 
the automotive or the newspaper business. Whether it is through face-to-face, voice-to-voice or bit-to-bit interactions between buyers and sellers, the message is to create a meaningful experience. Products and services are currently transforned into interactive formats. The new Britannica is a high end CD-ROM product both in terms of content and World Wide Web connectivity. Currently, it is reasonably successful in its new role as a portal to meaningful content in this era of information overload (Evars and Wurster 2000).

\section{Shift in semantics or paradigms?}

With the increase of interactivity in marketing by, among others, the World Wide Web, the question of What Went Wrong with the oft-quoted McLuhanism, the medium is the message imposes itself. As information is digitized and decontextualized, the various carriers can be used interchangeably and the traditional chain between the medium and the message is broken. The word 'media' no longer refers to the media or the traditional mass broadcast media. Rather, the semantics have shifted back to its original connotation, plual and bi-directional ways of information conveyance (Mckenna 1997). Mass communication needs a critical mass as customers. Content is designed to meet the requirements of the bell-shaped curve of the normal distribution. Frequently, mediacrity leads to mediocrity. However, as the overriding fascination with the medium itself is wearing off, the meaning of any commercial offering assumes centrality (Samarajiva 1998). Furthermore, as the proliferation of media progresses and the costs of bandwidth and memory collapse, both media and messages are becoming commoditized (Pine and Gilmore 1999). Instead, the meaning generated by the interactive experience becomes the value-added component (Modahl 2000). The meaning of a product or service emerges as the result of a series of interactive experiences that customers have, rather than on the basis of a projected brand image. Information and communication technologies, Internet-related features, such as interactive kiosks, intelligent software agents, virtual malls and interactive television and video modules, have been catalytic in advancing the concept of 'interactivity' to the center of marketing's attention. These inciplent 
forms of dialogue between customers and suppliers alleady have a profound impact on the ways of doung business.

However, are we witnessing and I will put forward the big issue right away, a paradigm shift it think not from the start, the discipline of marketing has advanced the notion of 'dialogue': Marketing departments have attempted to establish and maintain relationships with customers, since the invention of the sales force, postal services and the telephone (Finegar, Kumar and Sharma 2000). Marketing theory abounds with the motion of dialogue and pleas of listening and responding to the voice of the customer and yet there has been a fixation on the historically sacred $p^{\prime} s$, which essentially are exponents of a mass marketing paradigm (Webster 1998). However, the advent of digital information and communication technologies not only has the potential of dialogue through a wide range of interactive media, it is also rendering the meaning of traditional marketing concepts irrelevant. Arguably, adherence to 'fixed prices', "premium location' and 'products with any color as long as it is black' holds the thread of a 'roadblock to progress' (Webster 1998). Therefore, let us not get stuck in the rhetoric of paradigms lost, but think through the relationship between medium, message and meaning in an attempt to reconstruct that old familiar construct of interactivity, which seems to be the best idea since sliced bread.

\section{Dialectic dialogue}

It is now possible, as well as necessary, for firms to think conceptually and practically about extending the scope and scale of dialogue. These developments have left marketing as a field in turmoil (Webster 1998). Schumpeter's metaphor of creative destruction comes to mind. it refers to the dismantling and reconfiguration of markets, distribution channels, organizations and products and services. New interactive media create new opportunities from selling books and music to financial services (Watson, Berthon, Pitt and Zinkhan 2000). At the same time, they are deconstructing traditional conceptions of markets and marketing (and the related concept of mass communication). A pioneer and innovator in the field of interactive marketing. Amazon.com, has 
rapidly developed into the world's biggest bookshop with a market capitalization that surpasses traditional booksellers by far. Traditional booksellers sell books. Amazon sells information about books: Amazon uses information to add value to books. When customers get an e-mail telling them that a new book has just been published and that it is just one click away, a customer experience is created that fosters customer loyalty. What Went Wrong with our local bookstores? Why can they not do this? It is not the Internet but the mindset that is the real issue. Not the medium, just a message. Bcoksellers have to stock an attractive selection of books. Paradoxically and in line with the post-modern tradition, Amazon's stock is limited, its selection limitless. And as Amazon is rapidly expanding its horizons to other forms of e-tailing, it is shaking up other markets as well. The metaphor of creative construction applies. Mediated environments are replacing the traditional communication and distribution channels. Processes of disintermediation and reintermediation are taking place simultaneously in many supply chains. Creative construction on the part of the consumer is replacing massive and passive distribution of products and services from suppliers to consumers. On-line auctioning companies (e.g., e-Bay) offer consumers the opportunity to create prices, whereas reversed electronic auctions (suppliers bid on specific consumer demand) create markets. Furthermore, with the help of venture capitalists, new markets are created through the establishment of virtual communities of shared interest and/or shared purchase intentions. The medium is the market.

Alternatively, electronic media allow customers to be creative in the production of a product or service. An instance reflecting the pastiche of the postmodern human condition is mentioned by Bishop (1998), who envisions that anyone in need of a new refrigerator could check out Marvelous Marvin's Freezer Emporium and their interactive Build-Your-Own-Fridge website. Furthermore, creative construction allows consumers to customize compact discs electronically and to combine Bach with Blef and the Backstreet Boys with Beethoven. After this giant leap, it is only a small step from the atoms of a compact disc to the bits of downloadable audio software, such as MP3. The medium is the product. Likewise, the wireless application protocol of mobile 
phones allows for personal pervasive connectivity and a context-based information offering, signaling consumers that the store on this particular block has product $x$ on sale or enabling them to download train or theatre tickets instantly. The medium is the service. Finaliy, the medium allows customers to create content. Nike, for instance, invites visitors to its interactive webisite to create their own movie clip by combining images and text, allowing customers to visualize and project at self-image in a mediated environment. The medium is meaning.

\section{A hyper-feality check}

We live in exciting times, or so it seems. For marketing management's marvel at the gizmos and gadgets of our brave new world and its consequent technological hype-cycle may also lead to a form of shortsightediness, an interactive technopia, as a result of which the medium runs the risk of becoming the message once again. As innovations in digital interactivity abound, it seems important not to lose sight of the old fashioned primiciples of relational exchange theory, of the emotions and cognitions in customer-company interactions. Well-established and well-studied constructs like trust, satisfaction and loyalty are inextricably related to interactions, whether these take place in hyper-reality or in a retail outlet.

My message is simple. Marketing has been and will always be about managing a mutually meaningful dialogue with customers, irrespective of the medium used. The fact that it is now possible to actually practice what has been preached for a long time posits the need for a new research agenda, one that allows us to conceptualize and make empirical sense of interactivity in marketing by blending what we know with what is happening at dizzying speed around us: Notwithstanding the build up of e-commerce in the business press, a fundamental understanding based on empirical cause and effect relationships is by and large lacking. Therefore, the purpose of this address is to sketch the outline of an interactive marketing research agenda. Its table of contents peads as follows. First, I will address the concept of interactivity. Secondly, the results of recent empirical investigations into various forms of interactivity will be synthesized. I will discuss interactive elec- 
tronic services, customer interaction centers and the relationship between social and mediated interactions. Finally, "whll touch upon some of the explorations that are placed on the researct agenda for the coming years.

\section{THE RECONSTRUCTION OF INTERACTIVITY}

While intuitively appealing interactivity is a complex and nebulous concept that is not well understood (Heeter 1989; Stever 1992; Anderson 1995; Haeckel 19981. This is partly due to the fact that innova tive interaction technology forces us to nuance established conceptualizations. An in-depth understanding of the marketing concept in the context of a global, digital enwironment is necessary for leveraging the interactiwe potential of marketing in today's competitive environment. At one level the new commercial enviromment is often simply a digital duplication of existing information and marketing. The result is numerous websites containing full-blown brochures or annual reports. This has been ironically referred to as "brochureware" "Ha and lames 1998; Siebel and House 1999). In today's environment what is needed is what has been called 'thick description'. This signifies that the multi-layered texture of socio-cultural reality should be taken into accourt. A visit to the Virtual Vineyards website not only offers goal directed features like product descriptions and ordering options, it also offers experiential feature such as the possibility to ask questions, product related trivia, wisualizations of recipes and chat options in a wine and cheese gathering community. It is literally, as well as figuratively, the electronic grapevine. This turns the wisit into an almost sensory experience, which is only one step away from the real-time interactive simulated holodeck experience of science fiction series. Interactive marketing is all about meaningful experiences. Spalter (1995, p. 172) states that the essence of the interactive format is whether it drat matically entances the customer's experience'. As a way of disentangling its complexity and reconstructing the concept, I discuss five principles of the interactivity concept. 


\section{Access-on-demand}

The first principle is access-on-demand in both sender and receiver commumication roles. Exchanges are avallable when users want them to be, or according to the philosophy of a famous beverage manufacturer 'any lime, any place, anywhere. To interact with custoners companies must have established multiple customer touch points, varying from toll-free numbers to web-enabled inks. The number of queries made through these touch points is expanding rapidly tha 1999). This suggests that more and more customers are looking for company access and customer suppoit. With the proliferation of access, the space in which interaction lakes place is no longer fixed and distinct. For businesses, the challenge ahead is to integrate their access points and to develop an optimal customer access mix.

\section{Synchronicity,}

The second principle is synchronicity, or the flow of multiple bi-directional information exchanges. Many books (including university blockbooks) and joumals are offered and periodically delivered in their digitized printed formats on the Internet: More than 5000 newspapers hawe an on-line version, the majority appears in exactly the same format ass its printed counterpart. However", the activity of reading an electronic magazine or newspaper becomes an interactivity only if the reader is enabled to request, change and add to its content in a way that is suited to his or her personal needs on subjects such as stock quotes and the weather or react to advertisements. This requires a stream of requests and responses by means of which the meaning of an object is defined. Closed-loop feedback, or real time response, using media that can handle the immediacy of bi-directional communications are essential for catering to the need for speed of the contemporary consumer. Call me back buttons, voice ower internet protocol, co-browsing and application sharing. chat and video conferencing facilities for question and answer sessions are some of the recent technical solutions for optimizing synchronicity in interactive marketing: Finally, with the advent of intelligent agent sotwware has become possible to establish interaction with objects in the mediated environment in real time: 


\section{Constructive activity and control}

From this follows the third principle of constructive activity and control, rather than passive exposure and dependence. Many products and services are moving from a fixed to an executable format (Choi et all. 1997). This signifies that buyers can exert control over the form and contents of products and services (Stever 1992). Customers may select and even add information. Computer manufacturers engage their customers in constructing personallized systems. Courier companies engage customers in tracking shipments at their convenience via Web parcel tracking software. Phone companies are offering customers the opportunity to manage and review their bills online. Copier manufacturers have their users monitor the maintenance status of their machines that use remote diagnostic technology to call in and schedule an appointment for the service engineer. Interactive TV is euphemistically referred to as 'do-TV".

\section{Timeliness}

The fourth principle defining the notion of interactivity is timeliness. In an interactive environment, customers generate transactions to retrieve information varying from the weather broadcast to stock data and news updates (e.g., Pointcast). These information services are associated with deadlines. The meaning of the service is either defined explicitly by customers and sellers or it is defined implicitly as a context requirement. If the information is not acquired before the deadline, its value becomes obsolete. Information services, such as airline and hotel reservations, are time-dependent and need regular updating if they are to be considered as truly interactive. That is why Seiko's message watch uses a real time satellite updating with a minimum of 36 times a day. Likewise, market intelligence becomes increasingly real-time dependent and a company"s timely response to signals of customer dissatisfaction seems crucial.

\section{Selfoptimization}

The final principle is self-optimization. The response made by one actor is contingent upon the expression by the other actor. Spalter (1995, p. 174) explains this symbiotic attribute of interactivity as follows" "as 
users interact wh the content whin a market space, a cycle of success can be created wherein corrtent attracts users, users create more content and new content enharces the value ${ }^{\prime \prime}$. Book and CD recommendations on the basis of previous interactions and a listing of the preterences of similar customer profiles are used to optimize the interaction with Amazon customers: At the Del com site answers to customer questions are not only avallable from the neal technicians, but also from user boards that requenty have the experience and the answers that techncians do not Such context sensitivity, characteristic of human interactoins is currently being developed for human-machine interactions too. In addition to interactive voice response technology that has been implemented widely, so-called natural language technology is currently being developed. This context-sensitive technology combines language and meaning by summarizing extensive dialogue, by semantic searching and intelligent reasoning.

These are the principles that determine the interactive format of a product or service, as companies are moving from market orientation to interaction orientation. Customer preference for such an innovative orientation is frequently based on trial. If a company succeeds in stimulating its customers to explore the potential of interactivity, it will be a lot easier to translate interactive strategles into practice. The next step. therefore, is to identify how principles of interactivity may be conducive to their adoption and diffusion. Consequently, a series of experimental studies on the marketing of interactive electronic services will be discussed.

\section{(9) YOUR SERVICE}

Thus far, interactwity in marketing has been primarily associated wh prowiding infontation, expressing brand awareness and telling the corporate story in the virtual market place: Moreover, the use of virtual stcoretronts enabing sales transactions and the distribution of products has rapidly been enbraced as a second impontan function of interactive marketing by a growing number of companies. Conceptually, however, 
interactivity in these functions hardly adheres to the atorementioned principles. It is only with the growth of a third function of interactive marketing that organizations need to think seriously about the meaning of interactivity:

"From Chase Manhattan Bark to Thomas Cook Travel Group LL. companies are waking up to the need for so-called E-service. It takes many forms: schmoozing shoppers over the Web through e-mail and Web chats, or sophisticated solware that tracks buyers habits and supplies instant help. Done right, E-service can dish up more thath just digital warm-fuzzies. It can improve the bottom line. "Stepanek 1999. p 1)

As services have the unique characteristics of intangibility, heterogeneity, perishability and simultaneity, full-blown interactivity is needed to address the problems traditionally associated with these characteristics. There are several reasons for the increasing implementation of the e-service function. One has been termed the 'service multiplier effect' (Aberdeen Group 1999), referring to the fact that any e.business pres ence creates a demand for pre-and after-sales service activities. A self-service environment has atready been developed successulthy on-line, in which people can help themselves iry finding information and to buy a product (Earle 1999). This seli-service option has been directed primarily to the push of sales and intelligent interactivity in post-sales product support. Furthermore, the implementation of e-services extends the range of options for customers and the use of an enthanced service portfolio may improve the value of a relationship with a particular company for the customer (Alsop 1999). Finally, e-senice applications may considerably decrease the cost of service and allow for service differentiation and segmentation in service contracts (i.e., one segment of customers may be offered self-service only, while another is entitled to self-gervice as well as live interaction and support). As an extention of the do-it-yourself trend, customers are now increasingly demanding do-itforme services, supplementing as well as cannibalizing on existing service delivery formats. Consequently, banks, airlines, car rental companies, management consuling companies and educational 
institutions are increasingly opting for on-line service dehvery to meet e-customer demand (Forrest and Mizerski 1996). With respect to this wend, fwo issues are worth noting.

\section{Interactivity permeates the firm}

Oncecurring theme in e-service offerings is intra-firm interactivity. or the seamless incorporation of technology and customer-oriented functions (back and front officel within the frm. Earle 11999, p. 2) provides a good example that illustrates this theme:

What if you had an e-service that did travel planning for you and you could go to a single Web-site and do all of those activities from one place? And then, for example, if you were booked on American Airhines and your (night got cancelled (a plausible scenario). You d have to move to another airline. The system would automatically adjust everything else in your travel plan to accommodate to the fact you were on a different airline and you were arriving two hours later. Your car would be held for you, your hotel notified, and your dimner restervation rescheduled."

By linking all the processes that are important for the entire trip planning. an effectively customized service can be delivered. This effectiveness level would be much harder to obtain when these business processes and technologies would not be integrated. A customer relationship built in one chanrel could be destroyed in another, resulting in 'corporate amnesia'. Therefore, it seems important that the reconstruction of interactivity is not limited to boundary spanning functions and that it cuts across existing organizational structures.

Objects may be closer than they appear

With the prolferation of interactivity, the theme of information overload presents itself. Already, both the scale and scope of information availatsle to customers and suppliers has taken on draconianly daturing dmensions. As the electronic marketplace enables real-time price and comparison-shopping, for instance, customers are facing seemingly infinite choice sets. As a resul, new rules of competitive advantage hold 
and one of the central rules will be the ability to reduce interaction costs. This calls for information services that assist in reducing search; barganing and monitoring costs for micro segments of customers. This can be done via human interaction (e.g., by means of co-browsing). Altematively, intelligent software agents can provide information services. This breed of new infomediantes serve customers by taking independent actions of behalf of individual users, with explicit autonomy delegated by the user to perform information fittering (Lieberman 1999). Today agent technology has evolved to the stage where it can provide a personalized representative for information search, trading in equities and monitoring lectricity usage for individual consumers.

\section{E-serwice adoption and diffusion}

As interactive electronic services, ranging from the electronic provision of traditional services (services with an ' $\mathrm{e}$ ' in front) to intelligent cybermediaries are advancing rapidly, little is known about the way in which customers will welcome these innovations. How will customers deal with the credence and experience properties of e-services? And, are consumers willing to allow intelligent software agents to act on their behalf with respect to various forms of economic activity? For no matter how fast technologies develop, customer adoption is arguably a critical factor in realizing the market potential of interactive electronic services. In other words, eservice providers are lacing both a demand and an innovation risk and "there is little beyond relatively primitive click stream market research to substantiate a demand for interactive services" (Forrest and Mizerski 1996, p. 18).

Previous empirical research into the adoption of inmovations has uncovered several factors that tell us how attitude and behavior in relaton to innovations are formed (e.g. Rogers 1983, Ostund 1973). Frequently, rellative advantage has been identified as the most powertul attribute. Companies must establish strong reasons for consumers to purchase onm line. If they cannot get it cheaper, quicker, better; more easily and more reliably, why should they purchase on-line? Relative advantage in the case of interactive services could be operationalized in 
temis of alorementioned principles of interactivity, such as the conve nience of access-on-demand, the immediacy of synchronicity and the timeliness of information. For instance, real time access to financial intormation, ease of execution and cheaper execution prices ane imporlant reasons why an increasing number of financial traders are using e-trading services over more fraditional ways of service delivery. By emphasizing relative adwartage, on-line serwice providers are trading time for money and making a profit by leveraging convenience. A second relatant innovation aitubute, particularly applicable to services, is percewed risk. The problem of risk has increased considerably with the advent of on-line service providers. Not only are customers unable to derive quality cues from tangible aspects and do they have to release personal and/or financial information, they often do not know whether the service provider is "lig or small, new or established, legitimate or illegitmate 1 Hagel and singer, 1999, p. 10). The increase in information asymmetry in e-busmess leads to perceived risk as a possible barrier to e-service adoption. Reputation, brand development, endorsements and air tight and extraordinary guarantees will fill the risk gap. Finally, under conditions in which buyers and sellers possess asymmetric information when facing a market interaction, signaling theory predicts that organizational reputation can fill this informatton gap by substituting for unobservable service attributes (Boulding and Kirmani 1993).

\section{E-travel sorvice}

We tested the impact of relative advantage, perceived risk and onganizational reputation on customer perceptions of quality, trust and adoption intentions by means of an experimental design (de Ruyter, Wetzells, Kolenbrander and Kleijnen 2000). Role-playing scenarios were developed reflecting a hypothetical interactive electronic travel serwice, resembling the atorementioned travel planning. Two hundred and two respondents, who were randomly assigned to eight treatment conditions participated in the study. The analysis of the results revealed that respondents who were confronted with the high relative advantage treatment condition exhibited higher service quality perceptions of the euservice and were more inclined to use this type of travel service. No significant differences were found in rerms of the level of trust. This 
suggests that prospects do not view relative advantage as a factor that enhances their faith in the new service. With regard to (low) perceved risk and organizational reputation, we found that these promote irust, perceived quality and intention to use the enservice. These wo main effects were of the similar magnitude and considerably stronger than the effect of relative advantage. In addition a woway interaction effect was found of organizational reputation and perceived risk on trust. This signifies that a positive organizational reputation may compensate for the effect of the perceived risk associated with euservices. Apparenty, the cuttivation of a sitrong "emage" pays off. Furthernore, while it seens important to the relatively advantageous interactiwity benefits of access convenience, speed and timeliness, these are outweighed by opportunity to construct, control and optimize the meaningfulness of the content of the service.

\section{Talk to my agent}

In a series of three related experiments we looked at customers attitude towards the use of intelligent agents for the services of product search, stock trading and electricity monitoring (de Ruyter and Wetzels 2000a). We examined the impact of relative advantage, perceived risk and organizational reputation on percelved accuracy, outcome instrumentality and trust. The results for experiment 1 (product search) reveal significant main effects for the three experimental wariables, as well as a two-way interaction effect for perceived risk and relative advantage; the effect of uncertainty anxiety may be dampened by offering convenience. The results for experiment 2 (stock trading) underline the importance of our independent variables through total main effect significance. In addition, two interaction effects (perceived risk $x$ relative advantage and organizational reputation $x$ relative advantage) were encountered. In addition to the three main effects, a significant interaction effect between onganizational reputation and perceived risk was encountered in experiment 3 (electricty monitoring). Again, our results are indicative of the importance of relative advartage, perceived risk and organizational reputation in interactive marketing and of the fact that their interrelationships are contingent on the content of the interactive oftering. 
So tar, we have focused on customers evaluations of the new messages, or interactive service offerings, that companies are trying to mairket. In order to faciltate this, many companies have adopted a new business function called the customer interaction center. We will turn to this new medium now.

\section{CUSTOMER INIERACTION CENTERS}

Faced by the challenges of interactivity, many companies have established customer interaction centers the generic synonym for call, contact, web or assistance centers). These units serve as central hubs for customer access and are key sources of customer-specific information. The customer interaction center has been defined as a business function for blended, multipurpose (sales, servicing and marketing) and multicommunication media (telephone, Internet, e-mail fax, video and interactive television) that seeks to serve a wariety of constituencies. (customers, prospects, supply chain, distribution channel and selected employeesy in a centrally consolidated setting; using both human-assisted and self-service interactions (GartnerCiroup 1998, p. 2). Interaction centers frequently transcend geographic boundaries. Currently, an increasing number of companies are using e-mail handling facilities in India and the city of Mastricht seems a magnet for locating pan-European interaction centers. Customer interaction centers present several research challenges. However, while attention from the business press has been booming, virtually none of the challenges have been addressed in the academic marketing literature. Our challenge has been (and still is) to change this by instigating a variety of empirical studies on customer interaction centers. Here is a brief synopsis.

\section{Performance vs. interactivity metrics}

By and lange, customer interaction centers have beem presented in the business press as anedium. lndeed, the message has been the new medium tself. As a result, these new media have been typically defined in terms of information and telecommunication technology. Undoubt edly, the technology offers smart solutions to the problems associated 
with the need for interactivity, if only because they frequently have a built-in, perfect registration of their own performance. This makes it easy to justify and account for the large investments by interaction start-ups. Thus, the focus has been technological and efficiency-driven; rather than experiential and meanirgudriven. During the past few years there has been a severe emphasis on benchmarking and the identification of best practices. Massive collections of data points have been almost effortlessly gathered, varying from asa (average speed of answer), queue time to abandonment rate and the height of office walls. The ease of measurement guided by automatic reporting leads to the apparent belief that what is measured is important and motivates employees to better performance (Silverman and Smith, 1995). What may have started as a simple artifact of the technology (automatic call distributor technology automatically measures talk time so it is reported out to managers? comes to be believed as important. No one has asked the question "What Went Wrong?". Feinberg, Kim, Hokama, de Ruyter and Keen (2000) did. We undertook an empirical assessment of the relationship between customer satisfaction and over 300 of the so-called critical performance metrics. The results were astonishing. Of all of the critical operational determinants only 'percentage of calls closed on first contact' and 'average abandonment' have a significant, albeit weak, influence on caller satisfaction. We conclude that the emperor may not be wearing any clothes...

Thus, the question remains what are the attributes of customer-firm interactions that do matter? In order to manage well, one needs to measure well. Since the dominant medium that customers use to contact. interaction centers is still the plain old telephone system, Burgers, de Ruyter, Keen and Streukens (2000) attempted to map out customer expectation dimensions of voice-to-voice interactions. The aim of our study was to develop a measurement instrument that identifies key customer expectations with regard to the behavior of customer interaction center agents. Based on the (services marketing) literature, thirteen potential attributes were empirically tested on an effective sample of 206 respondents. This resulted in a confirmatory factor model, consisting of four different sub-scales that were labeled adaptiveness, assurance, 
authority and empathy. The results of the validity and reliabillity testing confirm the solidity of the measurement instrument. The four-sicale model holds interesting implications for recruitment and selection, training and monitoring of the behavior customer interaction center representatives.

\section{Interactiwity skills}

The basic skill for effective voice-to-voice encounters is undoubtedly listening behavior. Listening behavior has also been identified as an 'under-researched' behaviotal phenomenon in the marketing literature (Ramsey and Sohi 1997). Therefore, we undertook an empirical study aimed at zooming in on this type of behavior (de Ruyter and Wetzels $2000 \mathrm{~b}$ ). On the basis of a review of the literature, three dimensions of listening behavior were discerned: attentiveness, perceptiveness and responsiveness. Attentiveness is a sign of interactional involvement by the agent. Perceptiveness involves cognition aimed at assigning meaning to the message that is sent by the customer and digging deeper to come up with root causes behind questions and/or problems. Finally, responsiveness refers to the agent's response, which is essentially what customers are looking for in contacting the firm. An empirical study was designed to test the effect of these behavioral dimensions on customer satisfaction with the service encounter, the level of customer trust and the intention to contact the firm again. Two hundred and fifty customers who contacted the customer care center of a mobile telecommunications provider were called back for a telephone interview on the same day. By means of confirmatory factor analysis we obtained a good fit for the three dimensional structure of listening behavior. Moreover, the results of structural modeling revealed that attentiveness is a direct driver of encounter satisfaction, whereas perceptiveness is primarily related to trust. Also, the responsiveness dimension is related positively to both satisfaction and trust. In addition, we find a significant association between satisfaction and trust. Finally, both a satisfactory evaluation of the voice-to-voice encounter and the build-up of trust have a significant impact on the customer's intention to contact the call center again in the future. We conclude that customer perceptions of agent listening behavior are instrumental in maintaining relationships. 
The llip side of interactivity

Indeed, agents are instrumental. Yet, they are often caught in between the competing objectives of efficiency and effectiveness. The conflict between aforementioned performance metrics and the essenthals of customer satisfaction may create conflicting demands and difficult trade-off decisions and compromises: 'Should I make certain that the customer is maximally satisfied or should I try to get as many calls answered as quickly as possible?" Taylorism or tailorism? This and the emotional strain of dealing with dissatisfied customers in what is sometimes referred to as phone farms or bell batteries has lead some to conclude that working in a custonver interaction center is one of the ten most stressful jobs in today's economy (Coscia 1996). Role stress may" severely impede the return on technology investments and qualified employee retainment, and therefore, it seems important to simultaneously examine antecedents of role stress and its effect on center employee attitudes and performance. De Ruyter, Wetzels and Feinberg (2000) investigated which forms of empowerment and leadership styles decrease role stress and how this subsequently effects job satistaction, organizational commitment, performance and turnover intentions. It was found that particularly the autonomy dimension of empowerment has a role stress reducing effect. Interesting substantive direct positive effects of empowerment competence and leadership consideration on job satisfaction were found. Job satisfaction was found to be conducive to job performance. Furthermore, it was found that job satisfaction reduces turnover intentions, directly and indirectly via organizational commitment. Agents who feel they have the autonomy to perform their jobs have lower role stress which leads to greater job satisfaction, higher performance and lower intention to leave the organization. The simplicity of this path and the general correspondence to what has been found in organizations in the past (in general form) replicates what we know. At the same time, the path to job satisfaction is much clearer in the case of interaction centers; competence and autonomy are independent and influence different aspects of employee function, feeling, and performance. This makes interaction centers a unique research anvironment worthy of study and illuminates some very practical ideas on the management of this environment. 


\section{Returin on inter ativity}

We argued hat the reconstruction of interactivity in maketing may not only involve establishing dedicated interaction environments but that ul also requires the seamless integration of technology of the various front and back office units, applying the principles of interactivity within the organizational structure. In onder to bring companies in line with on line markets, many companies are investing heavly in information and communication technology. Neverheless it has remained empurically unclear what the Retum On Interactivty the new meaning of ROH has been in terms of financial accountabihty. Frequently, decistons are made based on intuition, comparing apples and pears, rather than relying on economically justifted cost-benefit analyses. Applying the principles of financial analysis to investment decisions concerning the interactivity within the firm, managers are able to make investment decisions that are aimed at optimizing the Return On Interactivity. Based on the principles of the service profit chain, Streukens, van Hoesel and de Ruyter (2000) attempt to model the impact of interactivity improvements, such as, for instance, feedback channels and mobile telephony. Based on the match of marketing and operations research techniques, the model forms the first integral test of the service profit chain and can be used to calculate the return on interactivity and to perform sensitivity andyses. Here is a verbalization of the chain of effects of a given scenario:

Company $X$ tecides to invest in improwing bottom-up communicat tion limprovernent action!. By allowing frontine personnel to make intranet-based conference cals with superwisors and a representative from top management whe a month, the interaction between several function layers is improved, resulting in a higher level of employee satisfaction, commitment to service quality and employee loyalty internal performance measures. This results in improwed remote and rechnical service ratings by customers fcustomer"s perception of performance on specific levell. This in retum has a posive sfict on we overall evaluation of the service by company $X$ (customer's perception of performance on generic level/ and may result even in higher overall customer loyalty scores in the annual customer survey. With use of internal information on contracts, the 
impact on the customer retention rate can be calculated lastomer retention. On the basis of this the retum on interactivity froceds of service contracu per customer can be calculated.

Thus far, the focus has largely been on the status quo consequences of the reconstuction of interactivity in marketing. In conclusion I will venture an attempt to define research themes for the road ahead. But not without an acronym.

\section{THE CONSTRUGTION OF MEANING}

Recently, Parise et al. (1999) reponted on a fascinating as well as amusing experiment concerming interaction behavior. They confronted respondents with different ypes of intelligent software agents: au agent resembling a person and an agent resembling a dog. Overall, respondents tended to interact and cooperate more with the person-mike agent in playing a social dilemma game. Dog-owners, however, alsolliked to interact with the dog-like sotwware agent. What, you might ask, are the implications for interactive marketing? Marketing has got to click to make customers click. Up to this point we have focused primarily on mediated interactions. Following Mcluhan and Fuore (1967), we posit that an in-depth understianding of mediated interactivity can only be achieved by studying so-called 'counter-enviromments'. This is interactivity in its richest form, the real or face-to-face service encounter. Without the medium, the message is meaning.

It must be ... emotional, experiential and engaging

How is meaning created in the natural environment? With the traditional ratio between price and quality fading, the modern face-to-face encounter can increasingly be characterized by the three e's: emotional, experiential and engaging. In a fragmented society in which sense-making seems less and less dependent on institutions like the church or local communities, carpet and home fumiture shop $A B C$ in New York invites their customers to "come to their senses". The new credo seems "I shop, therefore 1 am". Recognizing the need for social 
interacton among its customers, supermarket in Dallas organizes singles night every Thursday and a visit to Niketowns around the world is a purely emotional and engaging experience, which by far exceeds satisfying the (cognitive) need for a rew pair of running shoes. Donna Karan's gugantic store in London's New Bond Street looks more like an interior design Zen temple than a clothing store. The color of its clothes selection is carefully blended with the color of the interior. The Mall of America in Minnesota is one of the top three tourist attractions in the United States. More people go to the Mall of America than visit Disneyworld. Feinberg \& Evans (2000) conclude that malls are more than shopping areas. They may be mportant cultural, social, and psychological icons of the modern human condition. The French perfume store Sephora exhibits its products in an electrifying way and the London-based shop Lush thas turned selling soap into a multi-sensory emotional and engaging experience.

The evidence for the emergence of what Pine and Gilmore (1999) have termed the "experience economy" is not merely anecdotal. Using multi-level modeling, van Dolen, de Ruyter and Lemmink (2000) examined customer perceptions of the performance of sales persons during a visit to a fumiture shop. An analysis of 391 facedo-face encounters revealed customer evaluations of the shopping experience are determined to a large extent by social interaction attributes like mutual understanding, extra attention and the occurrence of positive emotions as well as sales person-related attributes such as competence and authenticity. Furthermore, on the basis of a reinforcement affect model of interpersomal attraction, Feinberg, Stanton and de Ruyter (2000) unequivocally demonstrate by means of series six experimental and survey designs that consumer's attuaction to a shopping center follows the same rules as interpersonal attraction. We argue that consumer preference and patronage are dependent on the reinforcement of affect, as a result of the proportlon of liked stores. In its richest and natural form the functionality of interactivity is supplemented by emotion, experience and engagement. 
So people who like dogs, like to work with dog-like soltware agents. The virtual agent is a representation of a real dog. The basic premise that applies here is based on the artistic principle of mimesis, i.e., the perception of the mediated experience imitates the natural environment (Steuer 1992). It is what the English poet Coleridge calls "the willing suspension of disbelief". In order to enjoy a mediated virtual experience, we temporarily pretend it is real so that we can experience the emotions; experience and engagement associated with social interaction. The message for mediated interactions is to mimic the three e's in order to create meaning. The Nike website is a frontrunner. At this site; customers cannot only order shoes, they can build them. In addition; interactive videoclips can be produced with a variety of endings; a customized sportsclip can be created and sent to a friend and desktop designs with Lance Armstrong images can be downloaded. Just do it, customers are stimulated to active engagement. Again, it is not the Intemet but the mindset that is the real issue. In other words, it is not the three W's, but the three $E$ 's that count in interactive marketing.

\section{Interactive research frontiers}

The message of constructing meaning in mediated environments holds the promise of a challenging interactive marketing research agenda for the years to come. I will conclude by briefly mentioning some of the key research frontiers.

First of all, it seems of paramount importance to establish trust in interactive marketing. Trust and related issues of privacy and security form the Achilles heel of the new market place. There is some evidence that monetary or convenience benefits do not instigate customers to lake the leap of faith (Hoffman, Novak and Peralta 1998). The context of economic exchange does not seem to be an enabling condition for sharing personal information. Instead, consumers prefer explicit disclosure and informed consent, indicative of establishing an explicit social exchange built on trust. We need to establish what the essential cues are for customers to exhibit a willingness to rely on interactive commerce offerings and to make the purchase click. We need to investigate how and why consumers use the new interactive technologies of today. 
Secondly, the natural question to ask is how emotions, experience and engagernent can be recreated in a virtual environment. Novak, Hoffman and Yung $(1999, p .39)$ have empirically demonstrated that the concept of flow is 'positively correlated with fun, recreational and experiential use of the 'Web'. Flow refers to the psychological state of an optimally enjoyable experience, resulting in convergence of time, place and perhaps cost-consciousness. It is like logging on to a website and discovering that it is suddenly two hours later and that the fire has gone out. It is like natural context activities like dancing or sking that fully captivate one's attention and lead to immersion in the experience (Pine and Gilmore 1999). The principles of interactivity are particularly conducive for customers to experience flow. Issues that need to be addressed are how to design a website for the facilitation of flow perceptions? Or which (inter)activities (entertainment, communication, exploration or learming) and technologies (video-conferencing, co-browsing or interactive TV) are flow enabling?

A third direction for future research concerns the development of reliable and valid interactivity metrics. Information derived from server logs such as visit time and browsing depth may very well suffer as aforementioned customer interaction benchmark parameters. Traffic flow should not be equated with experiential flow. Measures reflecting the consumer experience should be developed in order to be able to design a compelling interactive marketing offering. In these scale development efforts cross-cultural issues should be taken into account, as spatial convergence is removing geographical market boundaries. Moreover, a parallel issue to be addressed is to assess the ways and means of interactive data collection, using voice response or internet technology.

Fourthly, the interactivity principle of access-on-demand is taking on a new meaning with the introduction of wireless application protocol (WAP). So-called M-commerce applications abound, varying from entertainment to information and location services. The challenge ahead seems to mix WAP technology's unique propositions, such as personal access and contextuality and deal with the physical and informational 
limitations in order to provide a compelling service offering. Future research is warranted.

Finally, we need to introduce and explore the conceptualization of interaction cost theory. While interaction costs for customers may be lowered, for instance, with the help of software agents "click and mortar companies' suffer a considerable cost increase with the widening of interactivity options. It is has remained unclear whether the extension of interaction modes will have a supplementing and/or cannibalizing effect on existing media formats. One question that remains to be answered empirically is whether there are tradeoffs that can be understiood such that companies can develop effective multimedia strategies. Another equally important question to address is how to align the organizational structure with the strategy of interactivity.

These and related issues are being addressed in the research of the members of the department of Marketing and Market Research of Maastricht University, as I speak. We attempt to interact as much as possible with partners from other academic institutions and industry. For with Marshall McLuhan (1964, p. 256) we believe that 'dialogue supersedes the lecture'. On that note, let me end this lecture, for I have nothing left to declare but my thanks. 


\section{DANKWOORD}

Tot besluit will ik graag een dankwoord uitspreken tot cen aantal mensen die voor mij bijzonder en belangrijk zijn. Voordat ik dat doe wil ik het College van Bestuur en de Stichting Wetenschapsbeoefening van deze universiteil bedanken voor deze voor mij zo bijzondere benoeming en het in mij gestelde vertrouwen. $k$ ben de organisaties die door hun financiele ondlersteuning hebben bijgedragen tot de instelling van deze bijzondere leerstoel, Mercedes Benz, Libertel, Randstad,

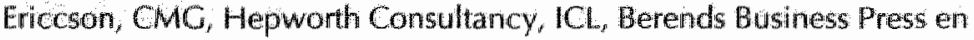
de Stichting Call Center College, zeer erkentelijk. Ook MMM productions (ook hier is geen sprake van een opzettelijke woordspeling) wil ik bedanken voor hun creatieve wormgeving van mijn presentatie.

Dan will ik graag Antoni Brack als eerste bedanken. Antoni, je hebt mij destijds de gelegentheid geboden om aan de Universiteit Twente een promotie voor te bereiden en vanaf de eerste dag dat ik daarmee begon wist ik dat dat was wat ik wilde doen. Je hebt me altijd ruimschoots de gelegenheid gegeven mezelf wetenschappelijk te ontplooien en mijn eigen weg te gaan. Ik denk dat ik nu pas goed kan inschatten hoe belangrijk dat is. Ook wil ik graag mijn Maastrichtse promotor Hans Kasper bedanken voor de creatieve, constructieve en interactieve wijze waarop hij heeft bijgedragen aan de totstandkoming van mijn dissertatie.

Verder wil ik graag uitspreken dat ik er trots op ben dat ik werk bij de sectie Marketing en Marktonderzoek van de Universiteit Maastricht. Ik wil met name mijn promovendi noemen; Marcel, Willemijn, $\mathrm{Ad}$, Sandra, Arjan en straks Mirella en Caroline. Door jullie enthousiasme en inzet krijgt het onderzoek dat we samen doen belangrijke impulsen. Ook wil ik Jos Lemmink persoonlijk bedanken. Ongeveer drie jaar geleden hebben we samen een visie voor onze sectie ontwikkeld en onder de bezielende leiding van los proberen we daar iedere dag in nauw overleg vorm aan te geven. Het resultaat mag er mu al wezen. $1 \mathrm{k}$ vind, Jos, dat we elkaar perfect aanvullen. Ook jij bent voor mij de ideale 
sparring partner en ik prijs me gelukkig met zóm beherend baas. Tenslotte, will ik Mantin Welzels noemen. Samen hebben we publicatie bergen verzet. Daanast wormt de humor die we daarbj deten woor min een belangrijke inspiratiebron voor de serieuzere zakkn des wetenschaps.

I would like to extend my gratitude to Richard Feinberg. As a colleague, of course, for all the joint work we have undertaken, but above all, for offering me such a rewarding and kind friendship. I feel honored by your presence here today. I also would like to thank jon Anton, call center guru extraordinatre, for an inspiring friendship that spans more than ten years.

Ik wil mign familie en vrienden bedanken, voor hum vriendschap, siteun en aanwezigheid vandaag. Ook hier will ik een paar bijzondere namen noemen. Allereerst mijn kleine grootste vriend Roel Meester. Roel, ik ben benieuwd of je na vandaag nog steeds geleerde will worden. Ik dank Bente, David, Maren, Joshua, Sarah, Christopher, Jeroen en Quinten om zo jong naar de universiteit te komen en voor het plezier dat we vaak samen hebben. Mijn goede vriend Norbert Scholl dank ik woot de kunst van het improviseren in werk, jazz muziek en het leven. Ik dank mijn schoonouders, Karel en José Vogt, voor het begrip en het mee leven dat ik steeds van jullie ontvang. Itk dank vooral mijn ouders. Jullie hebben veel mogelijk gemaakt en mij altijd en omworrwaardelijk gesteund in de wele wegen die $\mathrm{ik}$ in het leven heb bewandeld. Ik weet dat: jullie trots op mij zijn. Dat ben ik ook op jullie.

Mijn laatste boodschap is voor jou, Danielle. Jouw liefde, levens/ust en wijsheid geven ledere dag opnieuw betekenis an mijn leven. Ik besef heel goed dat ik hier niet zou staan als jij niet al die tijd naast mij zou staan. Ik dragg daarom dit medium met hart en ziel aan jou op.

IK heb gezegd. 


\section{REFERENCES}

Aberdeen Group (1999), "E-Service: Using the Internet to Manage Customers", www.servicesoftcom/presskit-whitepaper html, Servicesoft Technologies Inc: (lanuary).

Alsop, 5. (1999), "The dawn of E-service", Fortune, Voll. 9. Anderson, C. (1995), "Computer as audience", in Forrest, $E$. and Mizerski, R. (Eds.), Interactive Marketing. The Future Present, American Marketing Association, Chicago. pp. 149-62.

Bishop, B. (1998), Strategic Marketing from the Digitall Age, American Marketing Association, Chicago.

Boulding, W. and Kirmani, A. (1993), "A consumer-side experimental examination of signaling theory: Do consumers perceive warranties as signals of quality?" , Journal of Consumer Research, Vol. 20 (June), pp. $111-123$.

Burgers, A., de Ruyteli, J.C.; Keen; C. and Streukens, S., 2000), "Cus" tomer expected quallity in voice-to-voice service encounters", International Journal of Service Industry Management, Vol. 11 No. 2, forthcoming.

Choi, S, Stahl, D.O. and Whinston, A.B. (1997), The Economics of Electronic Commerce, MacMillan Technical Publishing, Indianapolis. Cosicia, S. (1996), Tele-stress. Relief for call center stress syndrome, FlatIron Publishing, New York.

Dolen, W. van, de Ruyter, J.C. and Lemmink, I.G.A.M. (2000), "Experiencing the chain of reactions. An empirical assessment of the influence of CCE behaviors on encounter and relationship satisfaction", manuscript under review.

Earle, N. (1999), "Chapter 2 of the Internet: New E-Services Promise a "Dorlt-For-Me" World" "http://www.products.novell.com/lead_stories/1999/feb25/index.html, Novell Inc.

Evans, P. and Wurster, T.S. (2000), Blown to Bits. How the New Economics of Information Transform Strategy, Harvard Business School Press Boston. Massachusetts. 
Feinberg, R.A., Kim, 1. Hokama, L., de Ruyter, 1.C. and C. Keen, C. (2000). Operational Determinants of Caller Satisfaction in the Call Center" "International Joumal of Service Industry Management, Vol. 11 No. 2, 6orthcoming.

Feinberg, R.A., Stanton, I., de Ruyter. J.C. (2000) "Attraction and Shopping Center Choice: A Reinforcenent-Affect Model of Interpersonal Atraction Illuminates Shopping Center Choice", manuscript under review

Feimberg, R. and Evans, C. (2000)" "It's a Mall Mall Mall Mall World" St. James Encyclopedia of Popular Culture, manuscript under review.

Fingar, P. Kumar, H. and Sharma, T. (2000), Enterprise Emcommerce. The Software Component Breakthrough for Business-10-Business Commerce, Meghan Kiffer Press, Tampa, Florida.

Forrest, E. and Mizerski, R. (1996), Interactive Marketing: The Future Present, American Marketing Association, Chicatgo.

GartnerGroup, (1998), Call Center Transitions, ESC10.

Ha, L. and James, E.L. (1998), "Interactiwity reexamined: a baseline analysis of early business websites", journal of Broadcasting and Electronic Media, Vol. 42 No. 4 , pp. $457-74$.

Haeckel, S.H. (1998), "About the nature and future of interactive marketing ${ }^{\prime \prime}$, Journal of Interactive Marketing ${ }^{\prime}$ Vol. $12 \mathrm{No}$. 1, pp. 63-71.

Hagel, J. and Singer, M. (1999), Net Worth, Harvard Business School Press Boston, Massachusetts.

Heeter, C. (1989), "Implications of new interactive technologies for conceptualizing communication", in Salvaggio, J.L. and Bryant, J. (Eds.), Media Use in the lnformation Age, Lawrence Erbaum, Hillsdale, pp. 217-35.

Hoffman, D.L., Novak, T.P. and Peralta, M. (1998), "Building consumer trust in online environments: The case for information privacy", Working Paper, Owen Graduate School of Management, Vanderbilt Universify.

Iha, A. (1999), "A million moments of truth", Messaging Magazine, Vol. 2. pp. B- 10 .

Lieberman, H. (1999), "Attaching interface agent software to applications" Working Paper, Media Laboratory Massachusetts Institute of Technology, Cambridge, Mass. 
Mckenna, $R_{*}$ (1997), Keal Thme, Harward Business School Press Boston, Massachusetts.

MCLWhan, M. (1964), Understanding Media, Routledge, London.

Mcluhan, $M$ and Frore, Q. (1967), The medium is the massage, Hardwired, San Francisco.

Melcher, A. (1997), "Dusting of the Brttannica",Business Week, 20 October, 143.

Modahl, M. 2000, Now or Never: How Companies Must Change to Win the Batle for nternet Consumers, Harper Business Press. New vork.

Novak, T.P. Hofman, D.L. and Yung, Y.F. (1999), "Measuring the flow construct in online enviromments: A structural approach" "Working Paper, Owen Graduate School of Management, Vanderbilt Universiny.

Ostund, L.E. (1973), "Perceived innovation attributes as predictors of innovativeness", Journal of Consumer Research, Vol. 1 (September), p. $23-9$.

Parise, S, Kiesler, S., Sproull, L. and Waters, K. (1999), "Cooperating with life-like interface agents", Computers in Human Behavior, Vol. If 5, pp. $123-42$.

Pine, B.l. and Cillmore, I.H. (1999), The Experience Economy, Harvard Business School Press Boston, Massachusetts.

Ramsey, R.P. and Sohi, R.S. (1997), "Listening to your customers: The impact of perceived salesperson listening behavior on relationship outcomes, Journall of the Academy of Marketing Science, Vol. 25 No. 2, pp. 127-37.

Rogers, E.M. (1983), Diffusion of Innovations, The Free Press, New York. Ruyter, I.C. de and Wetzels, M.G.M. (2000a), "Talk to my agent, Experimental studies into customer adoption of the intelligent software agent concept" , manuscript under review.

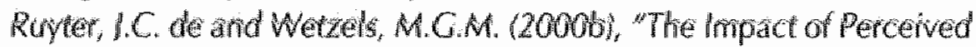

Listening Behavior in Voice-to-Voice Service Encounters", Journal of Service Research Vol. 2 No. 3, pp. 276-84.

thyter, I.C. de, Wetzels, M.C.M., Kolenbrander, D. and Kleijnen, M. (2000), "Customer Adoption of Eservice: an experimental study", thanuscript under review. 
Ruyter, J.C. de, Wetzels, M.G.M. and Feinberg, R.A. (2000), "Role stress in call centers: the effects of role stress on performance and satisfac. tion", Journal of Interactive Marketing, forthcoming.

Samarajiva, R. (1998), "Interactivity as though privacy mattered", in Agre, P. and Rotenberg, M. (Eds), Technology and Privacy: The New" Media Landscape, MIT Press, Cambridge, pp. $277-307$.

Siebel, T.M. and House, P. (1999), Cyber Rules: Strategies for Excelling at E-Business, Currency/Doubleday, New York.

Silverman, M.K. and Smith, C.S. (1995), "The effects of human versus computer monitoring of performance on physiological reactions and perceptions of stress, in Sauter, S. and Murphy, L.R. (Eds.), Organizational risk factors for jab stress, American Psychological Association, Washington, pp. 181-94.

Spalter, M. (1995), "Maintaining a customer focus in an interactive age", in Forrest, E. and Mizerski, R. (Eds.), Interactive Marketing: The Future Present, American Marketing Association, Chicago, pp. $163-188$.

Stepanek, M. (1999), "You"ll wanna hold their hands", Business Week, 3621.

Steuer, ). (1992), "Defining virtual reality: dimensions determining telepresence", Journal of Communication, Vol. 42, pp. 73-93.

Streukens, S., van Hoesel, S. and de Ruyter, J.C. (2000), "An empirical assessment of the return on service quality", manuscript under review.

Watson, R.T., Berthon, P., Pitt, L.F. and Zinkhan, G.M. 2000), Electronic commerce. The Strategic Perspective, Dryden Press, Orlando.

Webster, F.E. (1998), "Interactivity and marketing paradigm shifts", Journal of Interactive Marketing, Vol. 12 No. 1, pp. 54-55. 